مجلة علوم الإنسان والمجتمع.......................................................... حورية علي شريف

\title{
المردود التربوي للمدرسة الجزائرية
}

الأستاذة: حورية علي شريف، جامعة المسيلة، الجزائر

من أهم التحديات الـتي تشــل باسـتمرار اهتمـام القـائمين عـن التربيـة والتعلـيم في

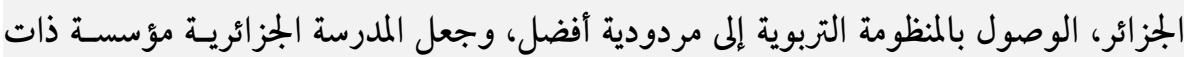

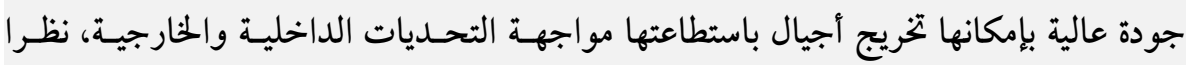

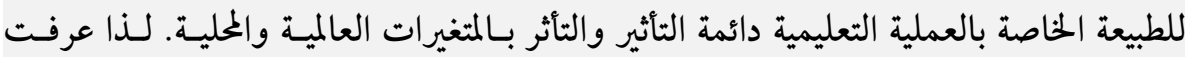

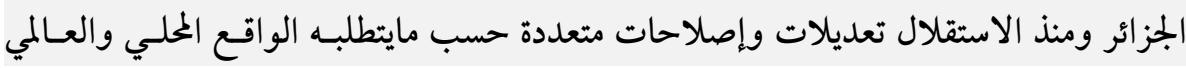

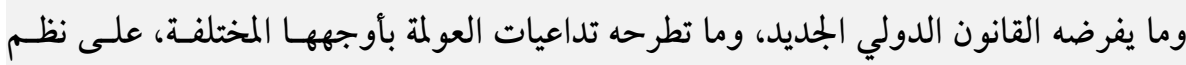
المجتمع عامة، وعلى النظام التربوي خاصة.

\section{summary:}

One of the most important challenges, that are consistently interest people of Education in Algeria, is to access to the best output of the educational system, and make the Algerian school an institution of high quality, that can produce generations able to face the internal and external challenges; this according to the special nature of the educational process; always affecting and affected by global and local variables .So, Algeria knew, since the independence, multiple modifications and reforms, according to what is required by local and global realities, and imposed by the new international law, and also by the implications of globalization, in its different faces, on the society systems in general, and on the educational system in particular. 


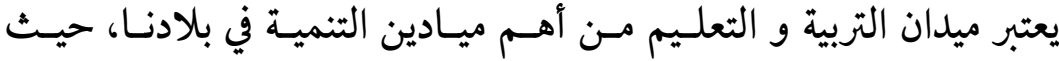

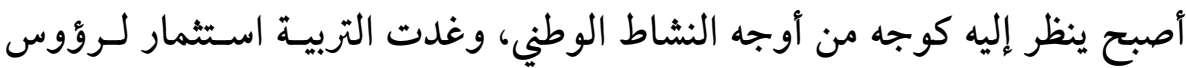

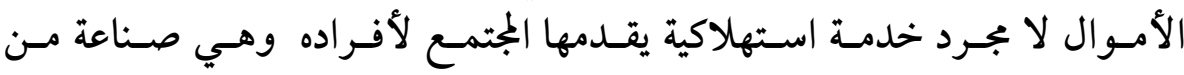

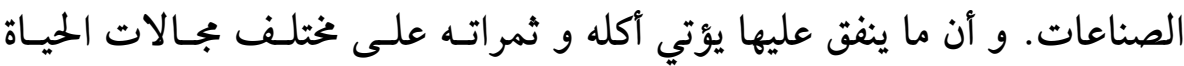

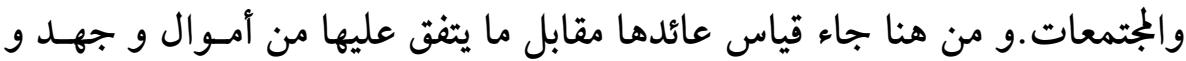

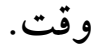

و يتوقف قياس مردودها في هذه المجالات على نـوع المؤشـرات والمقـاييس

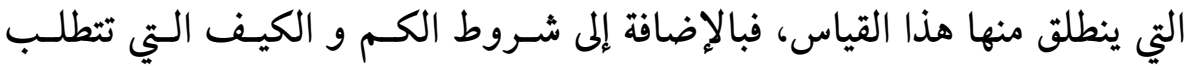

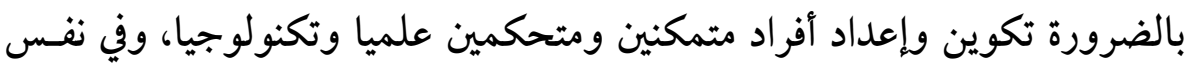

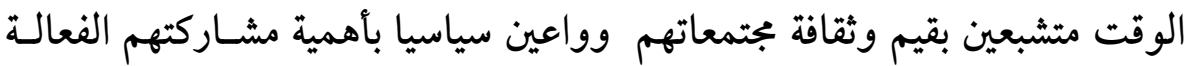

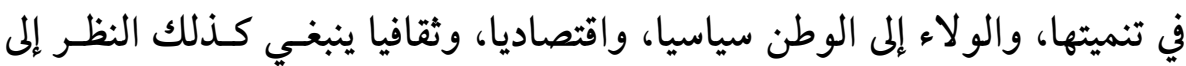

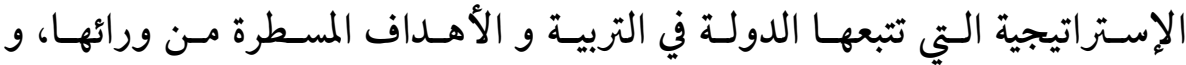

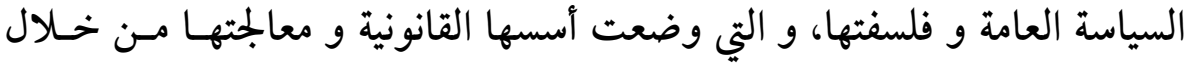

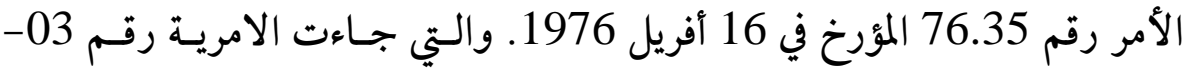

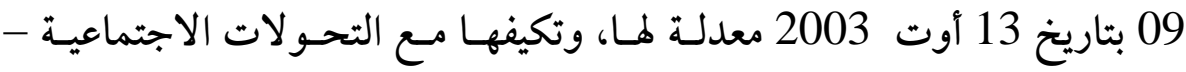

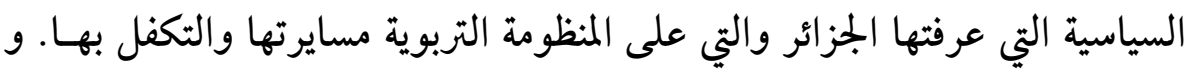
هي تشكل الإطار التشريعي لهذه السياسة:

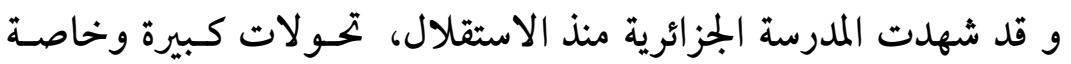

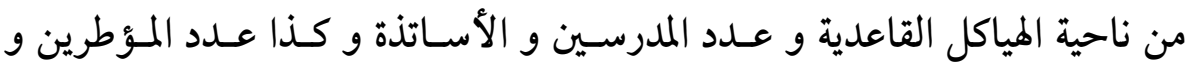

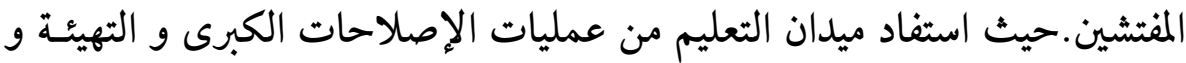

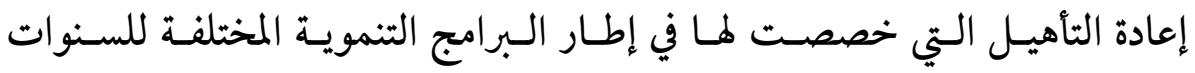

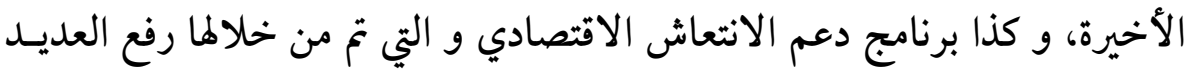
من النقائص التي كانت متراكمة. 
وبالرغم من هذه الانجازات والتحو لات إلا أن المردود التربوي للمؤسسـة

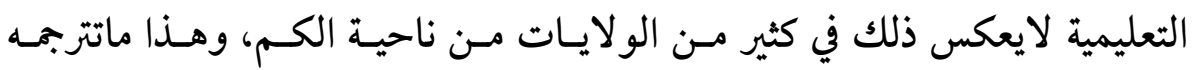

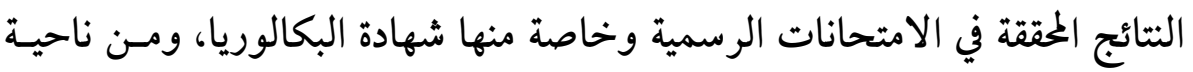
الكيف مازالت مخرجات التعليم دون المستوى المطلوب.

$$
\text { أولا : تعريف المردود التربوي : }
$$

المردود لغويا: عند المقبول يقال: رأي مردود، أي مرفوض، مردود أو عائد آلـة مـا

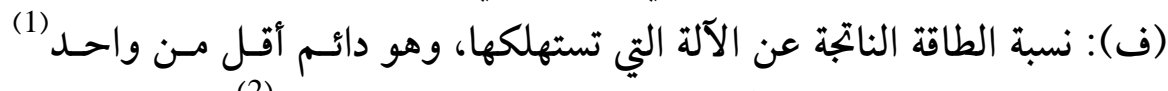

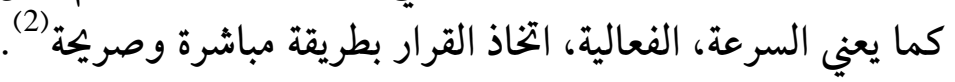

و اصطلاحا، يعتبر المردود التربوي من المفاهيم التي لها كثير من الدلالات

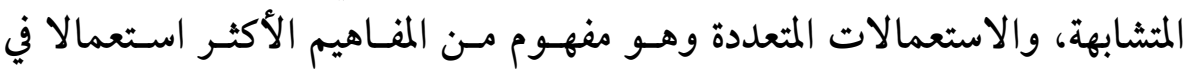

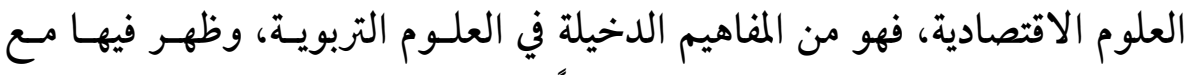

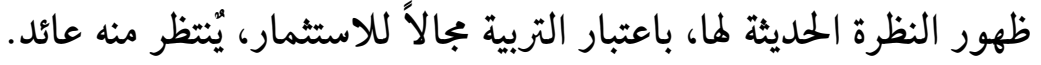

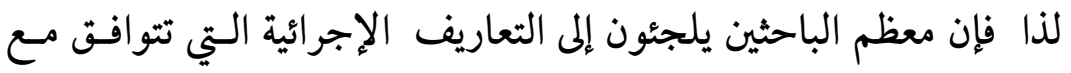

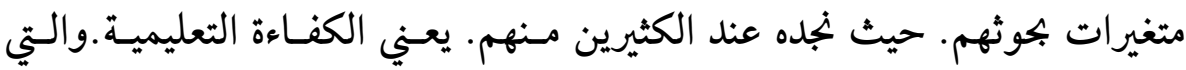

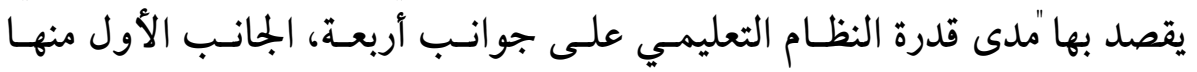

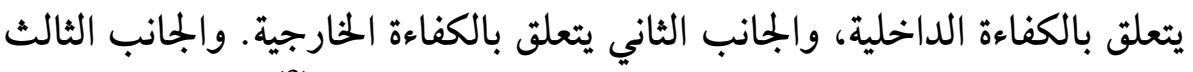

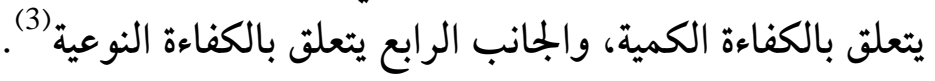
وهذا بدوره يشير إلى أن للمردود التربـوي جانبـان، جانـب كـبير، ويعني

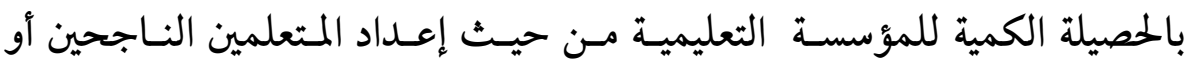

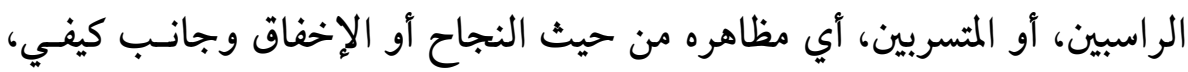

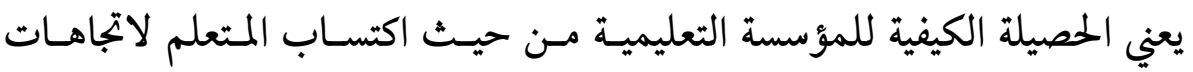

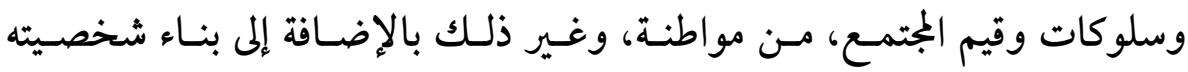

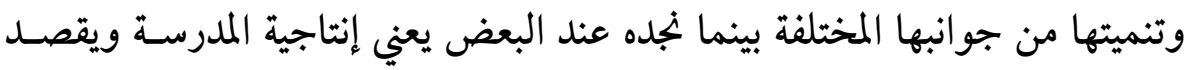


بها كل ما يجقـق زيـادة أو كفايـة أو فاعليـة، أو رضـا، وارتفـاع معـدل التحصسيل

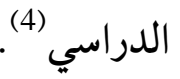
في حين نجد هناك من ينظر إلى العلميـة التعليميـة، إنتاجيـة التعلـيم وهي

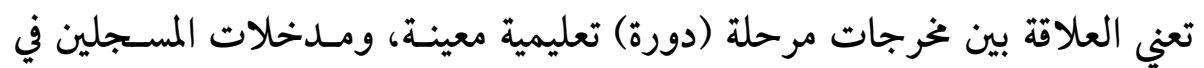

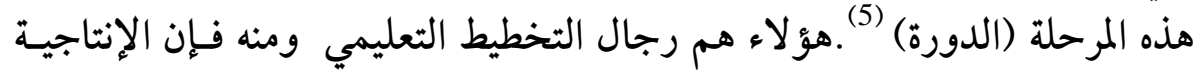

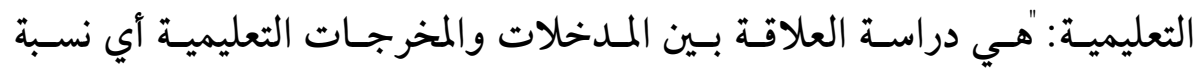

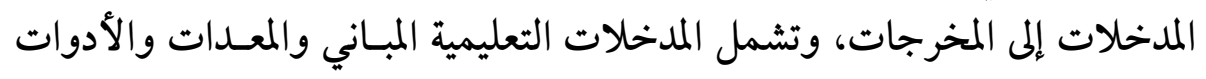

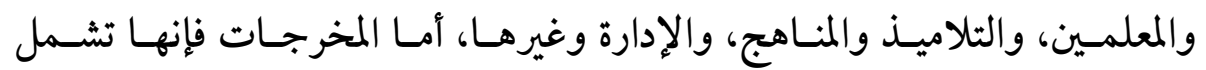

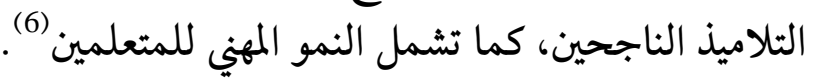
وهذا يعني أن المردود التربوي، هو النتيجـة المحصـلة مـن الفعـل التعليمي فئي

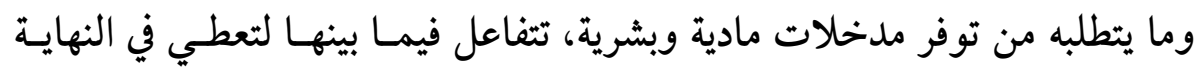

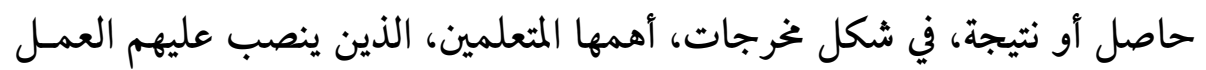

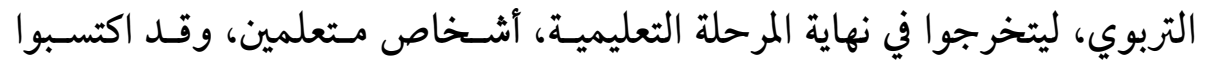
معارف ومعلومات، ومهارات واتجاهات وقيم.ومن مظاهره مايلي : ثانياً: مظاهر المردود الدراسي

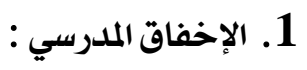

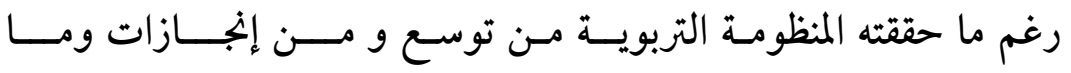

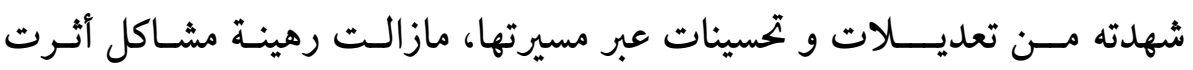

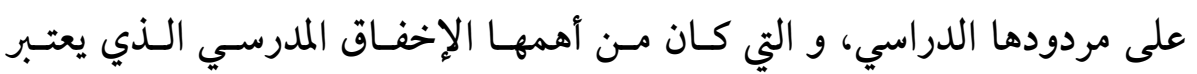

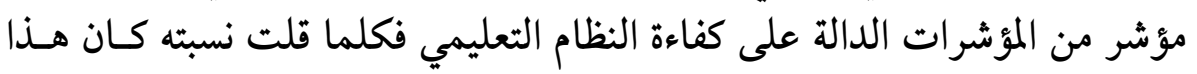
دليلا على فعاليته و كفاءاته بعناصره المختلفة، و كلما زادت كان النفان العكس. 


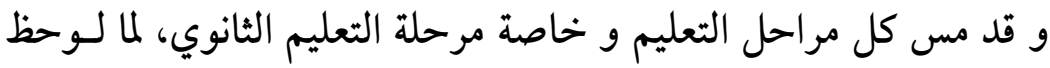

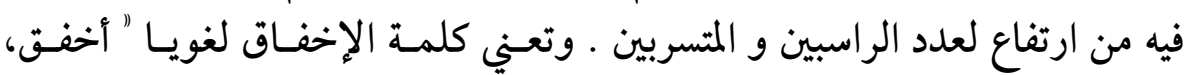

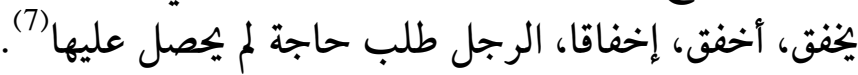

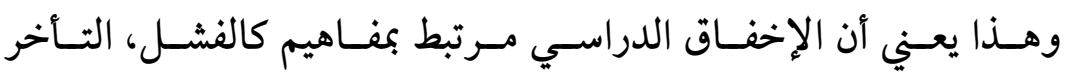

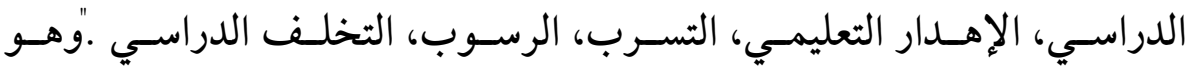

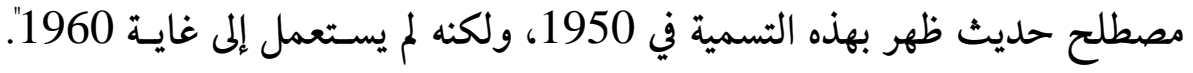
رغم أن لهذا المصطلح استعمالات منذ زمن بعيد_ولكن بمصطلحات مشابهة.

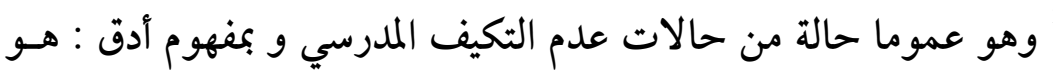

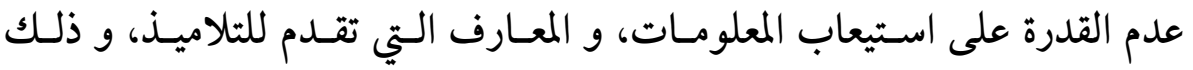

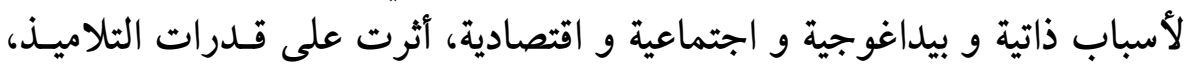

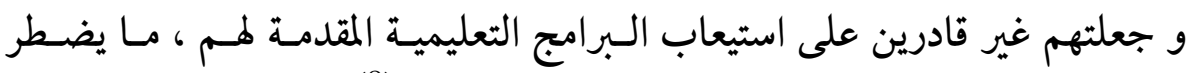

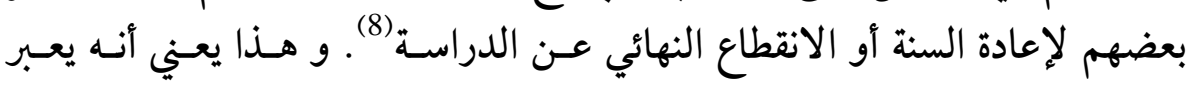

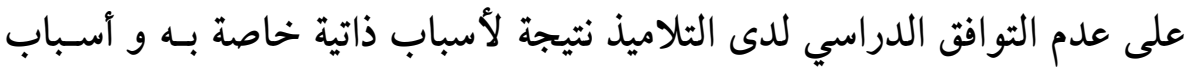

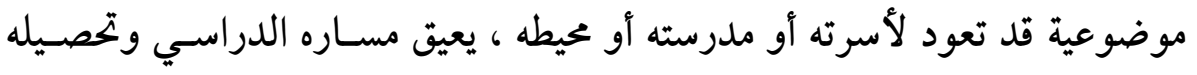
وبالتالي إخفاقه.

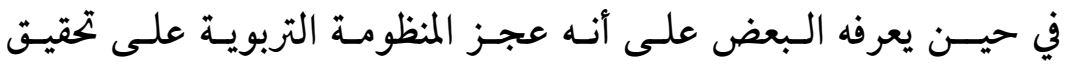

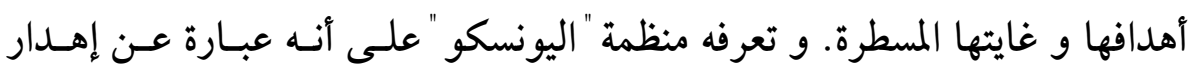

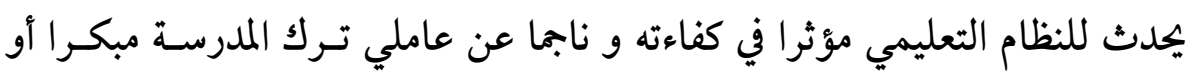

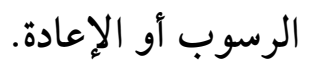

و من التعاريف السابقة نستخلص أن الإخفاق الدراسي عبارة عن إهـدار

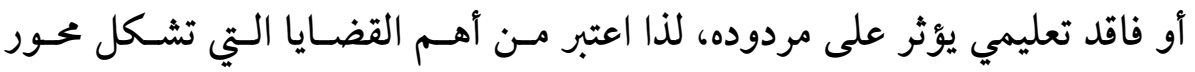

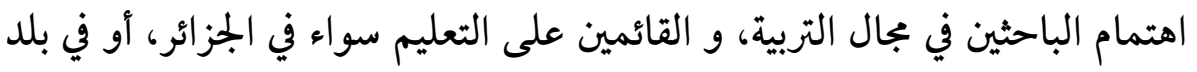

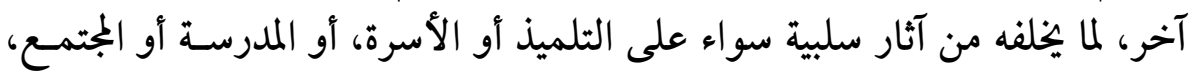

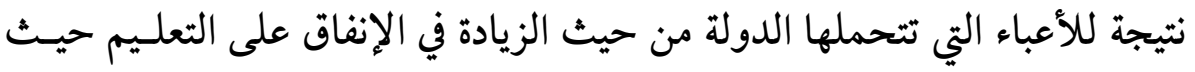


نجد" أن التكلفة الفعلية للتلميذ تحتسب على أساس عدد من أتمــوا التعليم بنجـاح

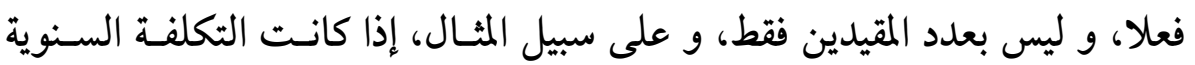

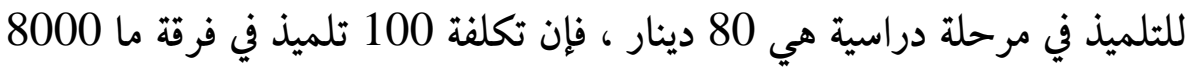

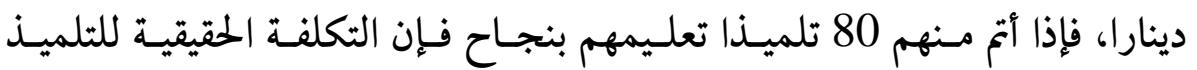

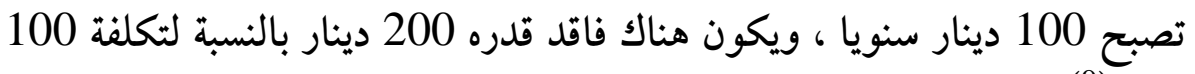
تلميذ (9).

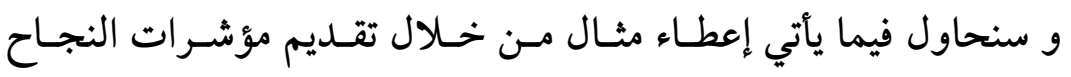

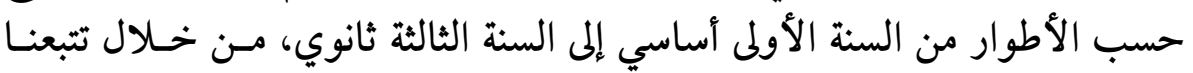

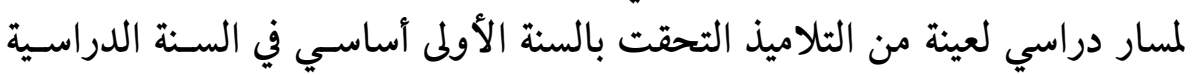

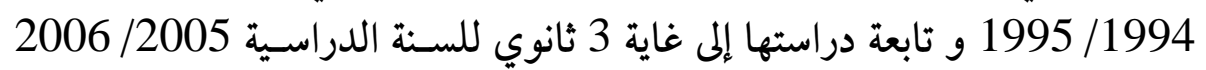

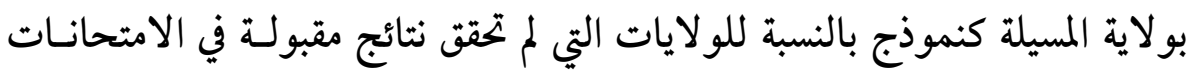

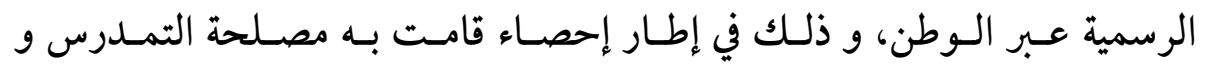

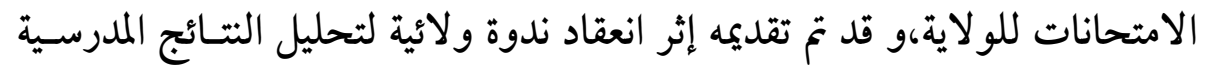

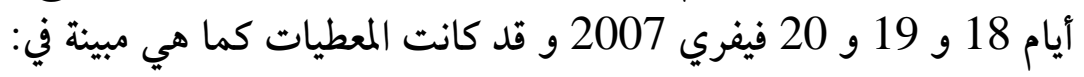
الجدول رقم(01): الذي يبين مؤشـرات النجاح حسب الأطوار مـن السنة الأولى أساسي المى فيلى

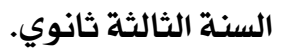

\begin{tabular}{|c|c|c|c|c|c|}
\hline مقارنة نسبة النجاح & نســــــــة & ناجـحون & مسجــلون & الدراسية الســــــة & 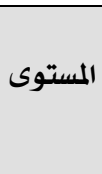 \\
\hline & & & 24473 & $\begin{array}{c}/ 1994 \\
1995\end{array}$ & س 1 \\
\hline 86.28 ٪ من س 1 أ & $\begin{array}{c}80.21 \\
\%\end{array}$ & 21116 & 26326 & $\begin{array}{c}/ 1999 \\
2000\end{array}$ & س 6 \\
\hline
\end{tabular}


مجلة علوم الإنسان والمجتمع........................................................... حورية علي شريف

\begin{tabular}{|c|c|c|c|c|c|}
\hline & & & 8231 & معيدون منمن & \multirow[b]{3}{*}{ س 7} \\
\hline \multicolumn{2}{|c|}{ نسبة الانتقال 73.93 \% من س11 } & & 18095 & جدد & \\
\hline & & & $\begin{array}{c}24454 \\
3338\end{array}$ & $\begin{array}{l}\text { معن00 } 2001 \\
\text { معهدون }\end{array}$ & \\
\hline 23.14 ٪ من س 23.12 من س 1أ & $\begin{array}{c}26.20 \\
\% \\
37.94 \\
\%\end{array}$ & " 5659 " 1 " 1 " & $\begin{array}{c}22108 \\
7152\end{array}$ & 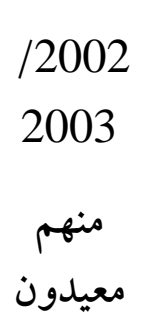 & \multirow[t]{2}{*}{ س 9} \\
\hline \multicolumn{2}{|c|}{ نسبة الانتقال 61.15 \% من س 7 ا } & & 14956 & 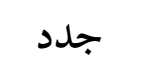 & \\
\hline & & & $\begin{array}{l}10618 \\
2230\end{array}$ & $\begin{array}{l}\text { /2003 } \\
2004 \\
\text { معندون }\end{array}$ & س 1 سا \\
\hline & $\begin{array}{c}40.13 \\
\%\end{array}$ & 4789 & 12065 & $\begin{array}{l}/ 2005 \\
2007\end{array}$ & \multirow{2}{*}{ س 3} \\
\hline & 56.08 & 3162 & 5638 & منهم & \\
\hline
\end{tabular}


العدد 04 ديسمبر 2012

\begin{tabular}{|c|c|c|c|c|}
\hline & $\%$ & & & معيدون \\
\hline من س 3 من سـ 1 ثنا & $\begin{array}{c}25.31 \\
\% \\
15.32 \\
\% \\
6.64 \\
\%\end{array}$ & 1627 & 6427 & جدد \\
\hline
\end{tabular}

المصدر : الندوة الولائية لتحليل نتائج الامتحانات الرسمية بالمسيلة، فيفري 2007، المشار إليها أعلاه.

و ما يمكن استخلاصه مما سـبق أن نسـبة الفاقـد التعليمسي كانـت عاليـة،

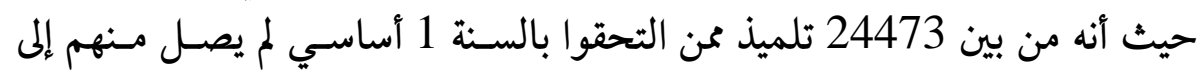

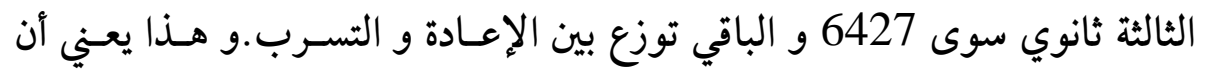

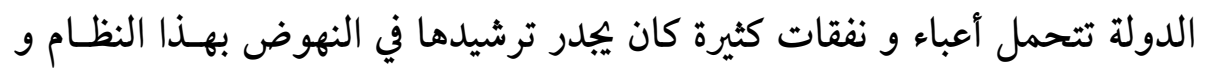

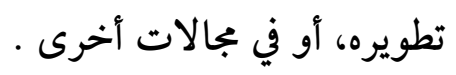

إضافة إلى ما يخلقه من آثار سلبية على التلميذ و الأسرة و المجتمع فبالنسبة

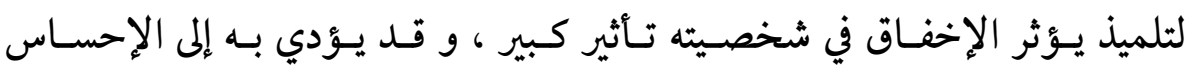

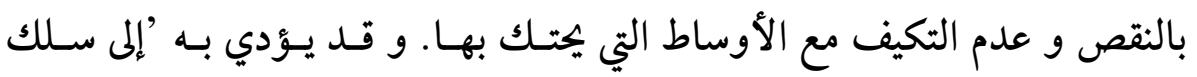

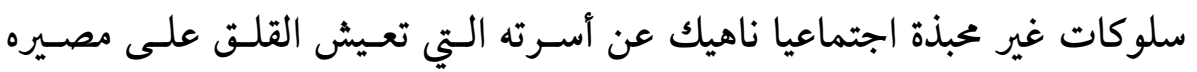

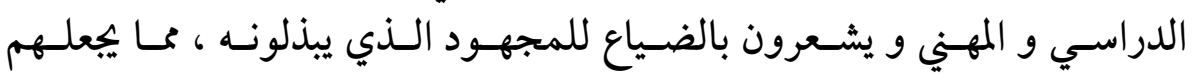

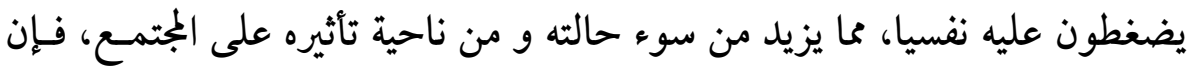

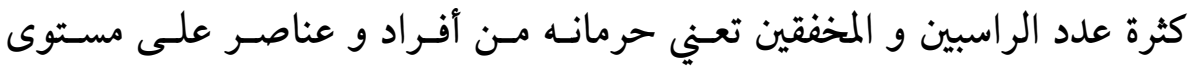

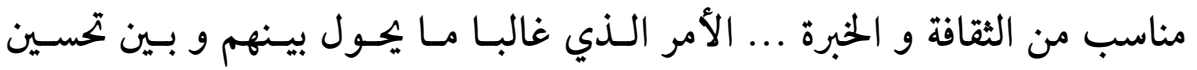


أحوالهم المعيشية، و الثقافية في المستقبل، و يكون عاملا رئيسيا من عوامل ضعف فعاليتهم و إنتاجيتهم كمواطنين ذوي مسؤولية (10)

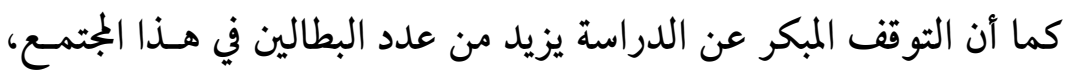

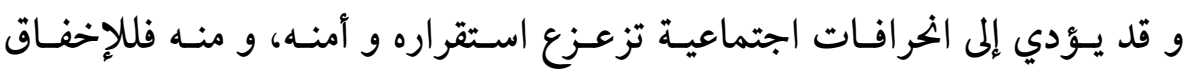

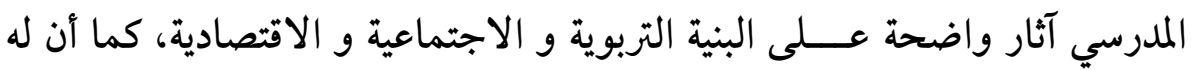

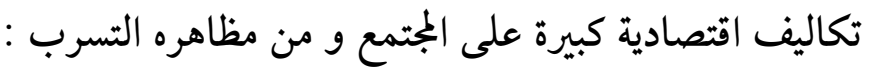

التسرب المدرسي: يعتبر من المشاكل الكبيرة التي تهدد النظام التعليمي و وتئي

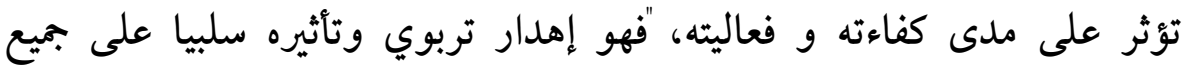

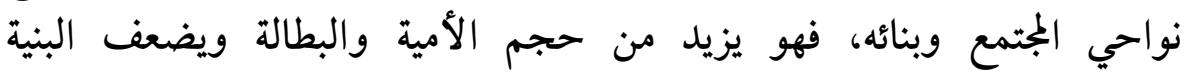

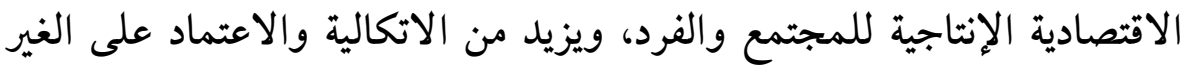

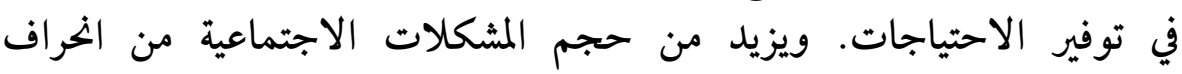

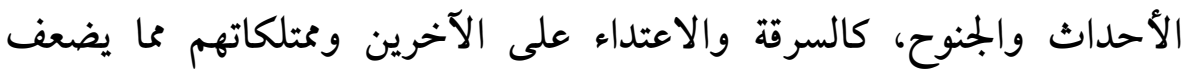
خريطة المجتمع ويفسدها (11).

لذا كان في مقدمة المسائل التي تحض باهتمام الأوساط التربويـة و الثقافيـة

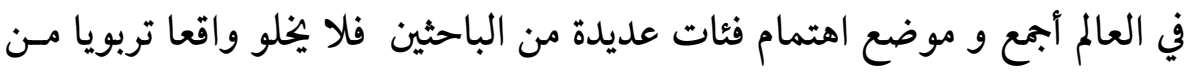

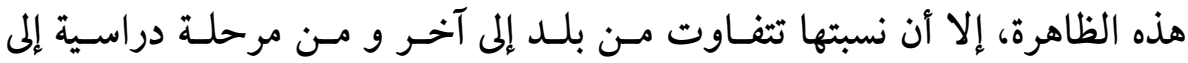

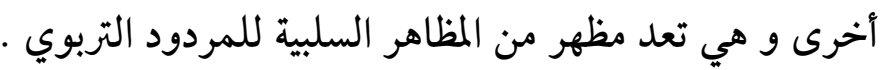

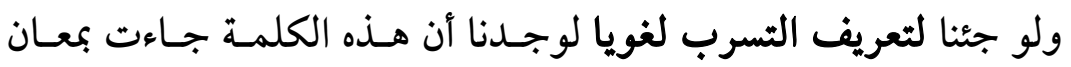

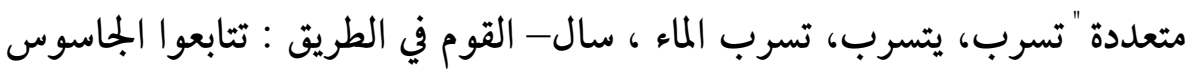

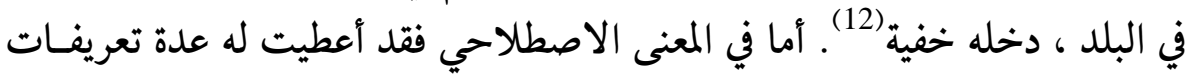

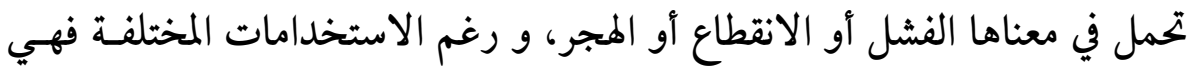

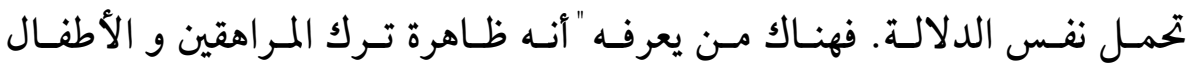

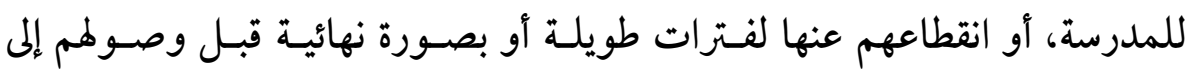




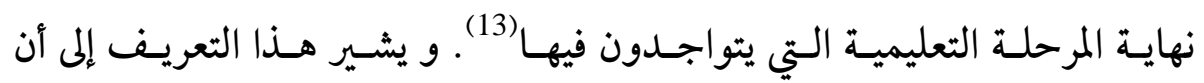

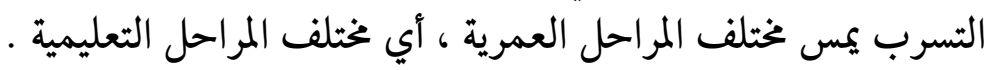

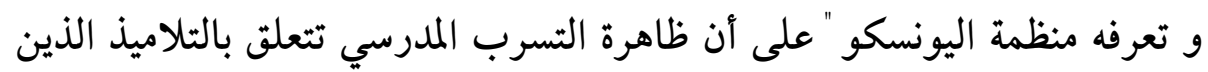

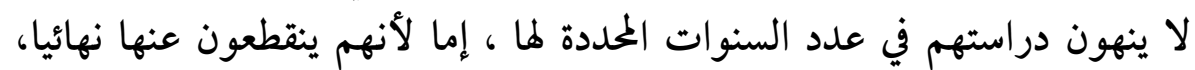
إما لأنهم يعيدون قسما (سنة معينة ) أو عدة أقسام ( سنوات معينة) (14).

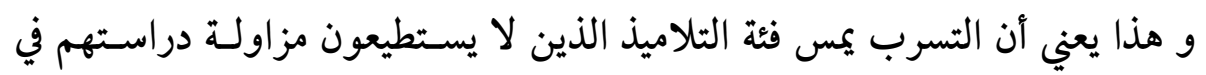

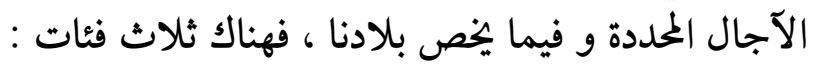

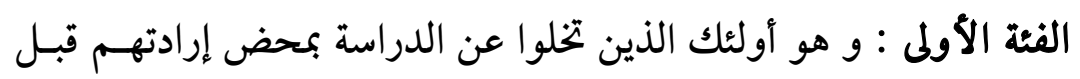
بلوغ السن الإلزامي 16 سنة خاصة في الوسط الريفي.

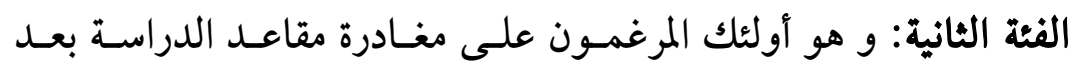
بلوغهم سن 16 سنة بسبب نتائجهم الدراسية.

الفئة الثالثة: و تخص مختلف المستويات لأولئك الذين ينقطعون لأسباب مادية (15).

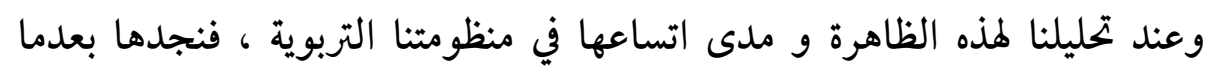

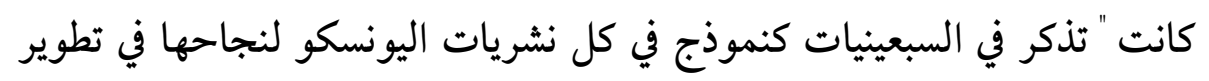

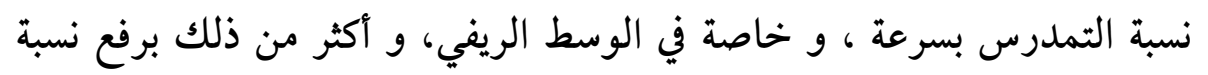

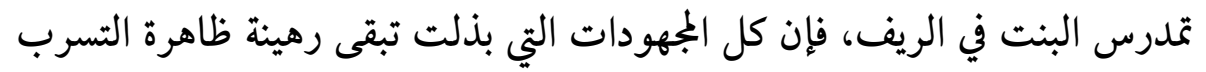

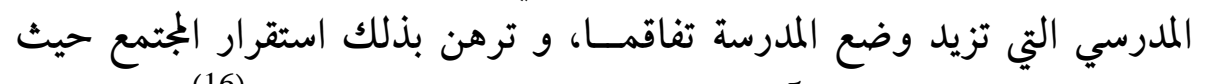
تسبب في تسرب و رسوب آلاف المتمدرسين على المستوى الوطني (16).

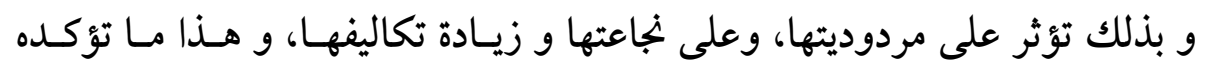

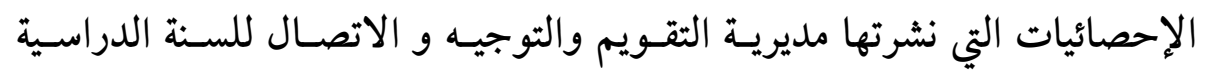
1999/1998 


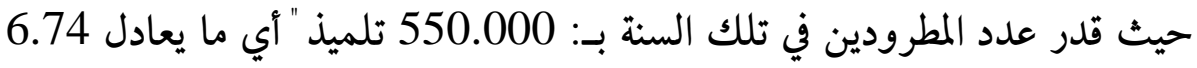
\% من التعداد الإجمالي" و93000 في السنة الثالثة ثانوي (17).

إضافة إلى هذا و من خلال تحليل مسار عينة من التلاميذ وفق معايير حددتها

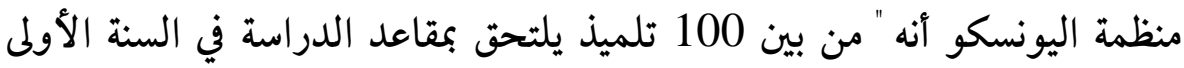

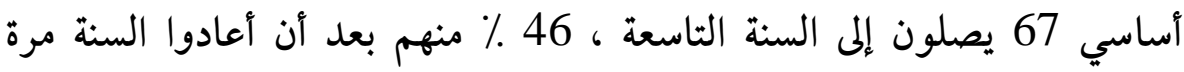

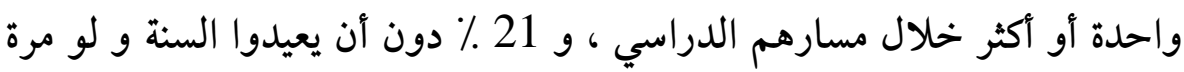

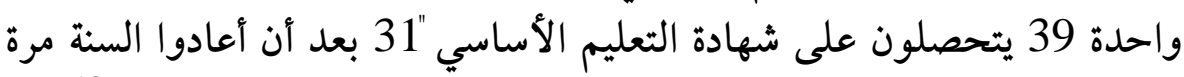

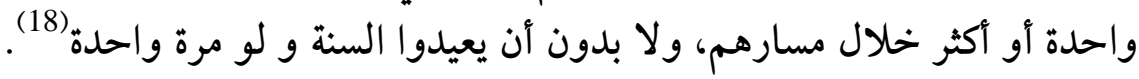

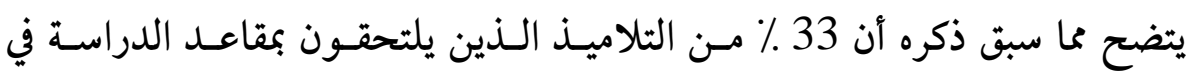

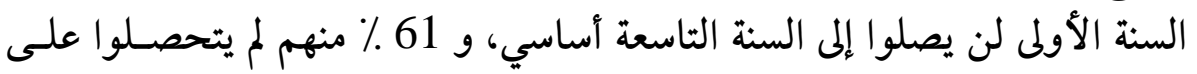

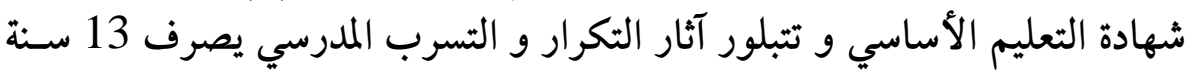

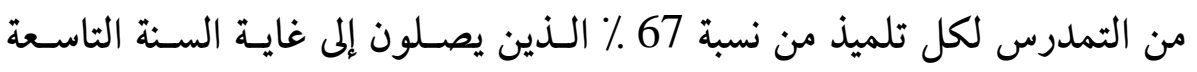

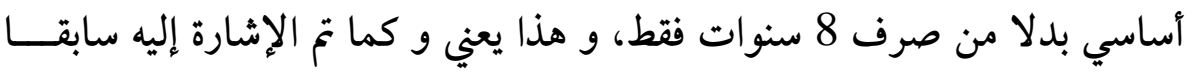

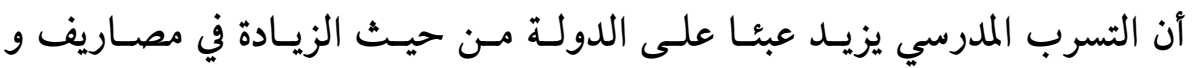

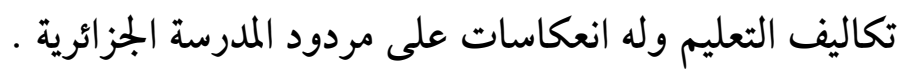

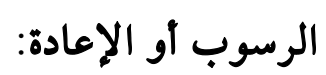

الرسوب لغة : "يرسب ، رسبا و رسوب الشيء في الماء سقط إلى أسفله ، التلميذ

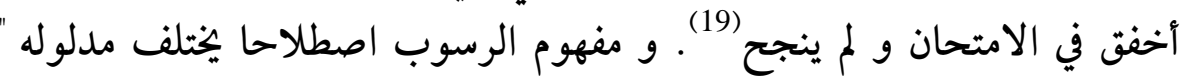

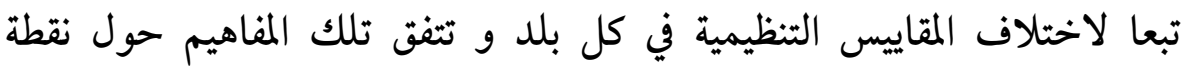

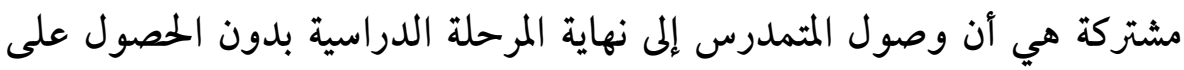

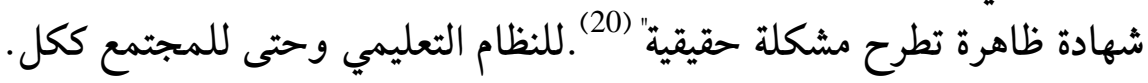


و هو " يعني رسوب التلميذ في السنة الدراسية لعدم إتقانه الحد الأدنى من المهارات و المعارف المتوقع إكسابها في هذه السنة و بذلك يعيد نفس السنة الدراسية، و و

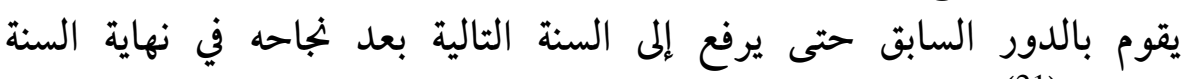
الدراسية (21)

ونلاحـظ أن جـل التعـاريف تتفـق علـى أن الرسـوب يشــــ إلى التلاميـذ الـذـين

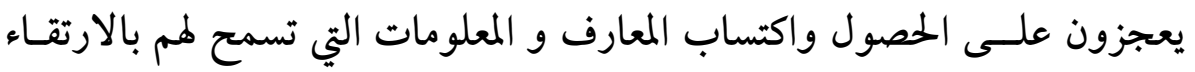

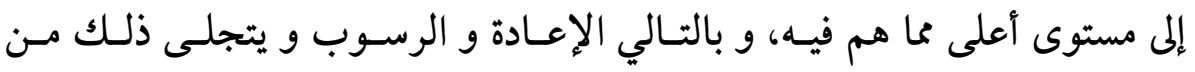
خلال الامتحانات.

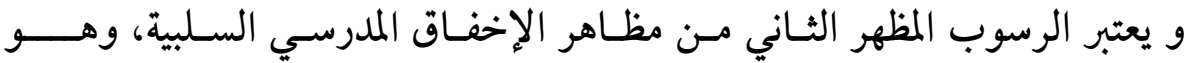

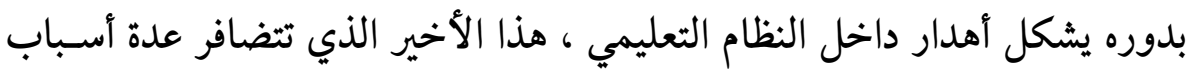

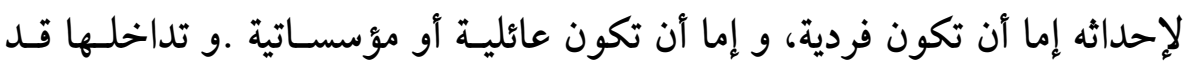

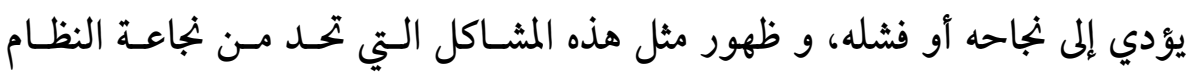
التربوي و مردوده.

و لمعالجة هذه الظواهر السلبية عمدت وزارة التربية الوطنية لاتخاذ أساليب المعالجة البيداغوجية و المتمثلة في عمليتي الدعم و الاستدراك، قصد التخفيف من حدتها

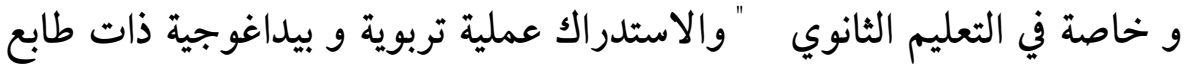
علاجي فردي، تهدف إلى تذليل الصعوبات المشخصة لدى بعض التلاميذ و معالجة الثغرات الطارئة في دراستهم (22).

و هي عبارة عن حصص إضافية تقـدم خـارج التوقيـت الرسمي ، و تشـمل فئسة

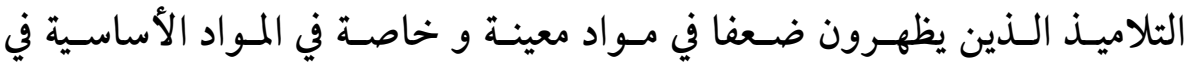

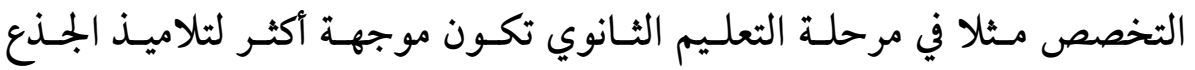
المشترك، و تهدف هذه الحصص إلى : 
تذليل الصعوبات الدراسية و معالجة الثغرات الطارئة في تحصيل بعض التلاميذ.

> القضاء على تباين المستوى من القسم الواحد و بذلك يتم تيسير مهمة الأستاذ التربوي.

> التقليل من ظاهرة التسرب و الرسوب و تقليص الإخفاق المدرسي تحسين المستوى و رفع مردودية التعليم (23).

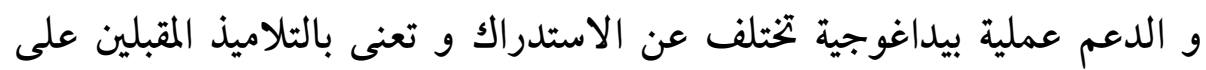

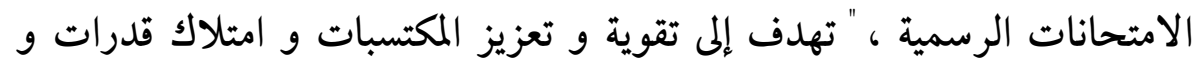

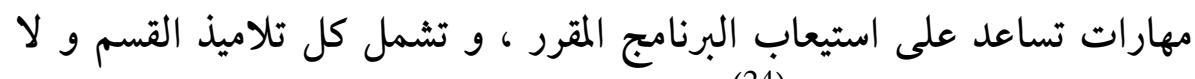
تخص التلاميذ الضعاف فقط (24). و تشمل على أنشطة متنوعة أهمها :

- مراجعة الدروس و تـذليل الصـوبات التي تواجـه التلميـذ في محتوى

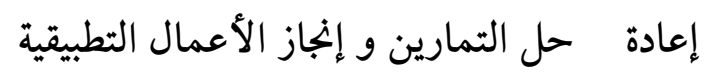
- تعميق فهم الدروس تصن

- تدريب التلاميذ على منهجية و أسـلوب معالجـة مو اضسيع الامتحانـات

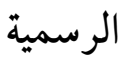

$$
\text { - مراجعة محروسة }
$$

و هي تنظم حسب إمكانية كل مؤسسة .

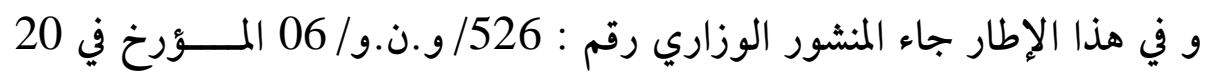

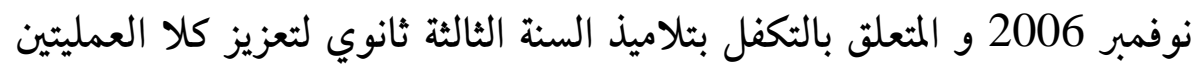

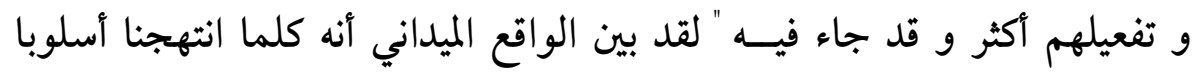


عقلانيا و حكيما في التسيير البيداغوجي و الإداري للمؤسسة التربوية لاحظنا

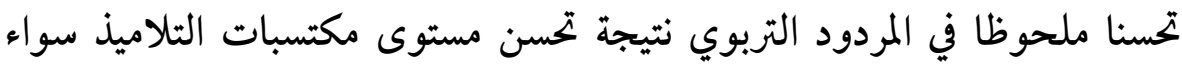

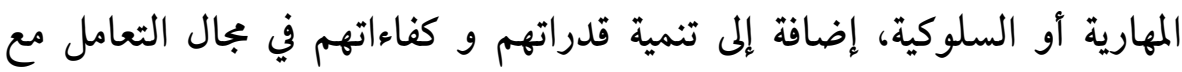

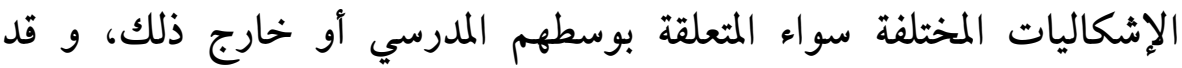

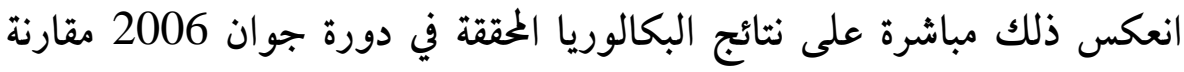

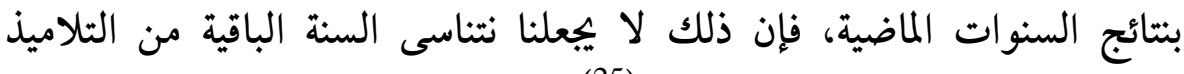

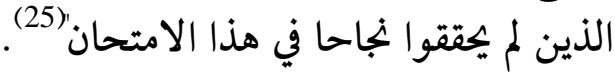

لذا حث على ضبط بعض الآليات التي من شأنها تحسين مستوى التلاميـذ

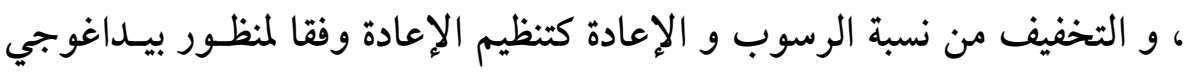

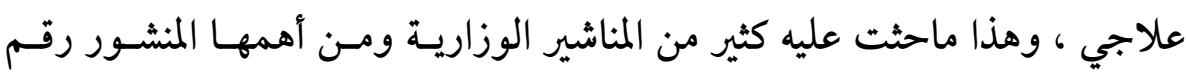

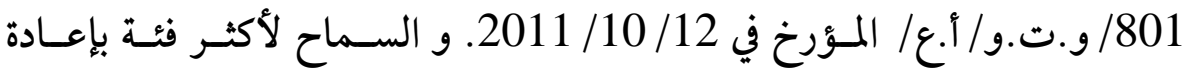

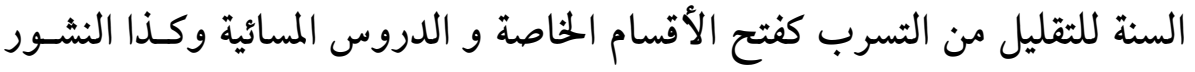

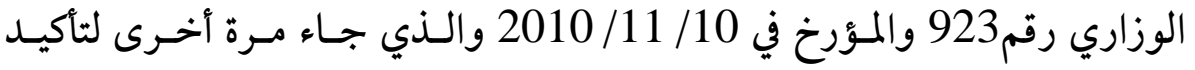

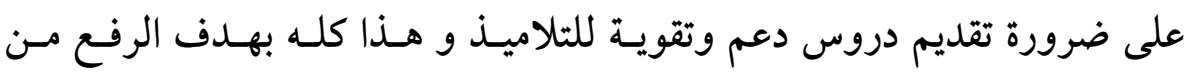
المردود التربوي لمؤسستنا التعليمية والقضاء على مظاهر الإخفاق المدرسي. ثالثا: المردود التربوي لمؤسسة التعليم الثانوي في الجزائر : شهدت ميزانية التربية تطور من حيث التسيير و التجهيز و الإحصاءات آلافئات

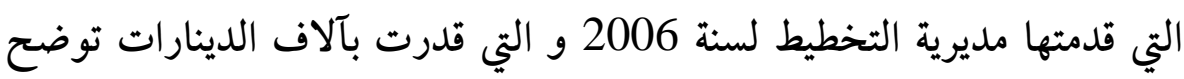

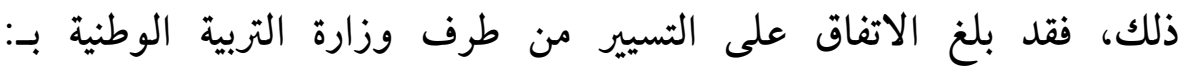
2220364.72 ، بينما قدر الاتفاق عليه من طرف الدولة بلدئ 1283446977

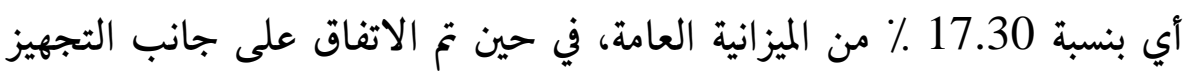

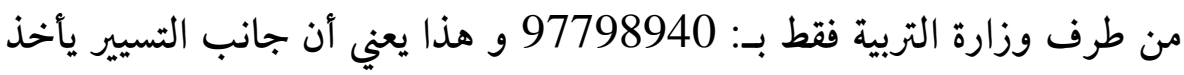

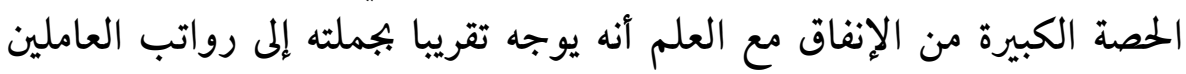

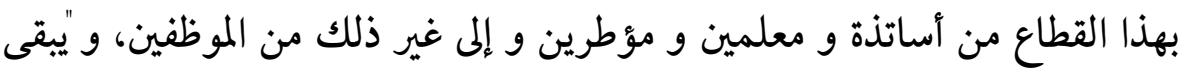


هامش قليل للتغطية البيداغوجية للتلميذ و المعلم في بجال التوثيق و التكوين، و و و التهية

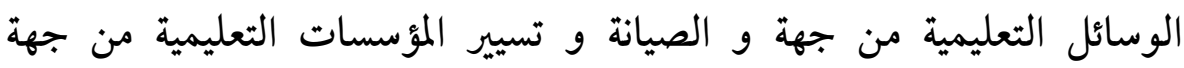
أخرى (26)

و خاصة في المرحلة الأولى من التعليم" "مرحلة التعليم الابتدائي " ، و رغم

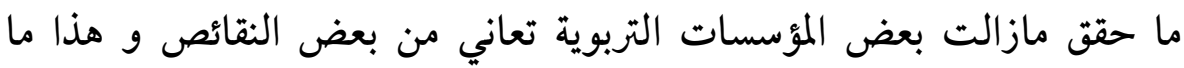

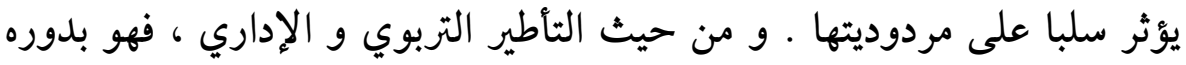

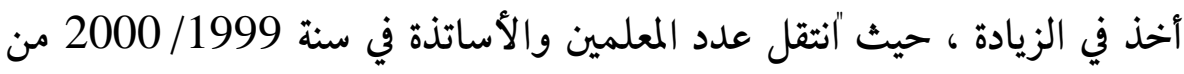

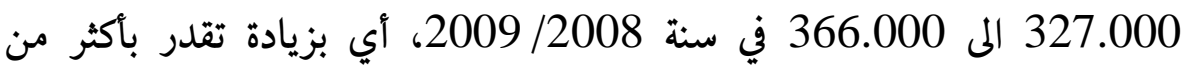
39.000

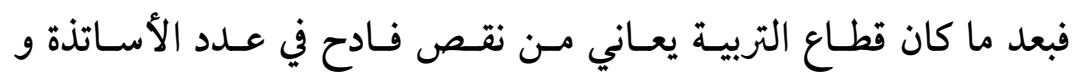
المعلمين ، و حسب الإحصائيات السابقة الذكر.

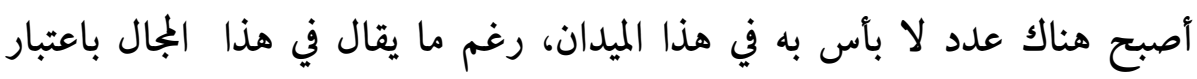

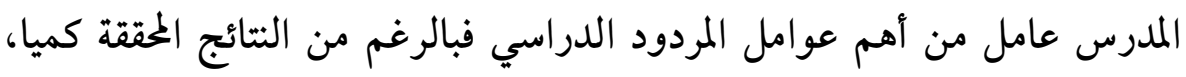

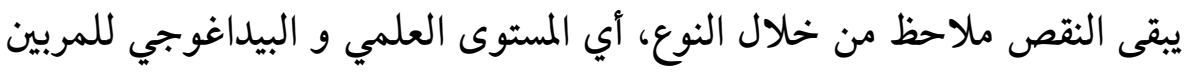

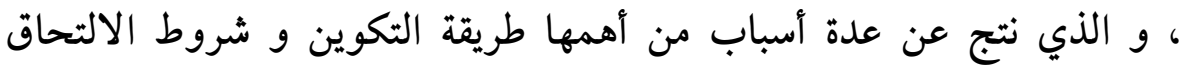

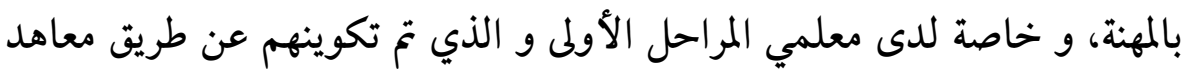

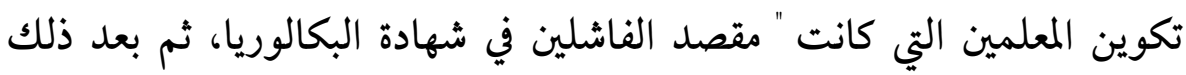

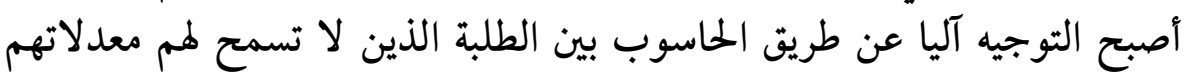

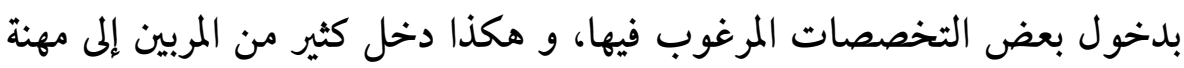

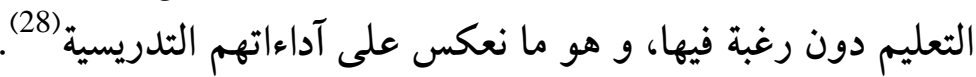

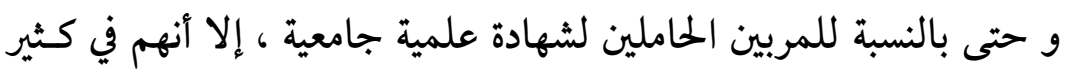

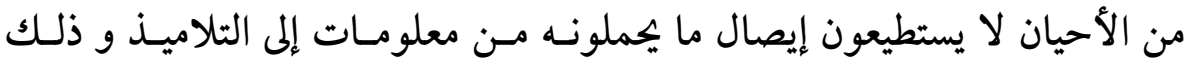

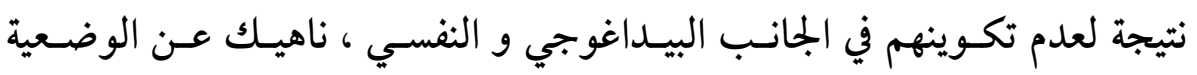

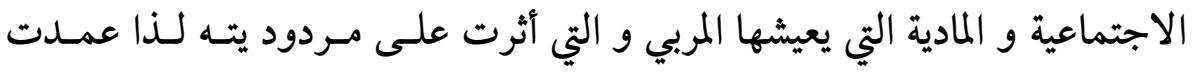


وزارة التربية الوطنية القيام بعدة عمليات فيما يخص تكوين المربين لتحسين أدائهـم

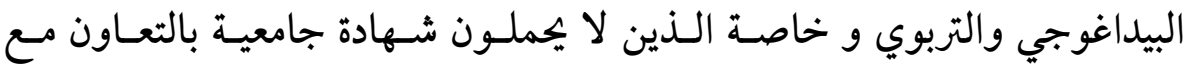

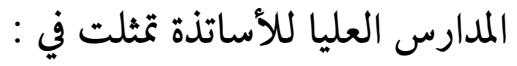

ل تحسين نظام التكوين الأولي للمعلمين ليتماشى مع المعايير الدوليـة في هـذا

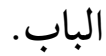

تطبيق نظام جديد للتكوين أثناء الخدمة يوجه خصيصا للمدرسين العـاملين في مرحلتي الابتدائي والمتوسط. ل التدريب المتواصل لإميع المستخدمين للتكفل على أحسـن وجـه بعمليـات إصلاح المنظومة التربوية.

ل إعادة تأهيل شهادة الأستاذ المبرز في الثانوي(29).

هذا من جهة، ومن جهة أخرى وفي مايتعلق بتحسين ظروفهم المادية

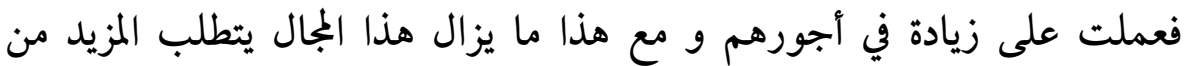

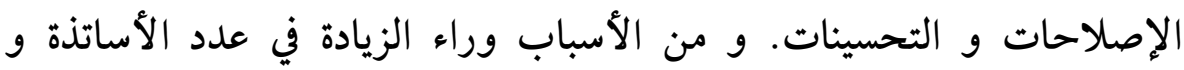

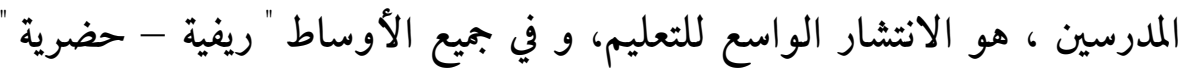

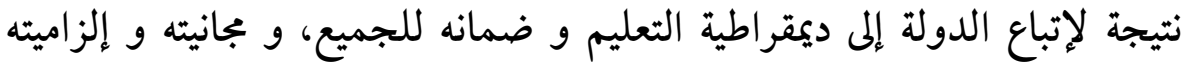

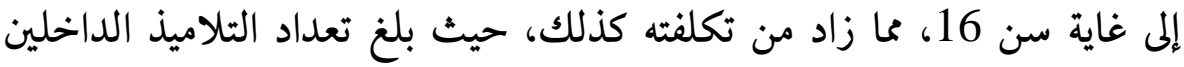
الجدد إلى التعليم الابتدائي حسب ماصرح به الدي الديوان الوطني للإحصاء سنة

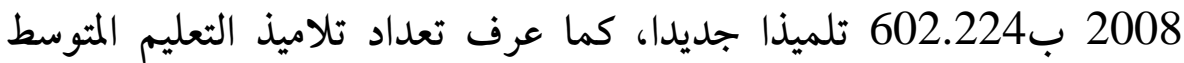

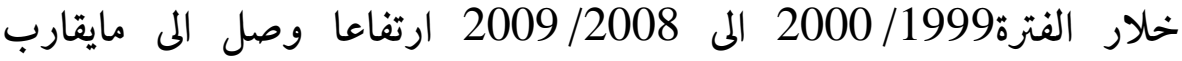

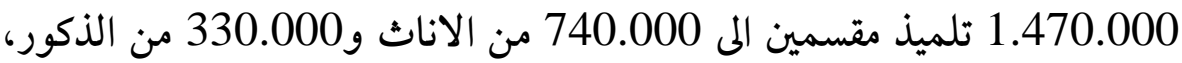

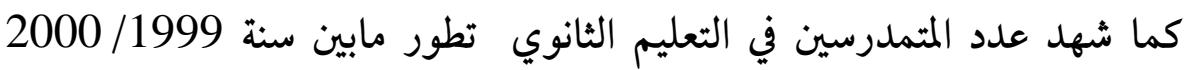
و2009/2008 بأكثر من 52.000 تلميذ موزعين بين واكثر من و3.900من الذكور28 
الأستاذة / حورية علي شريف...... مجلة علوم الإنسان والمجتمع.

ل و بالتالي يؤدي إلي التوسع في عـدد المؤسسـات التربويـة ـ والـتي شـهدت

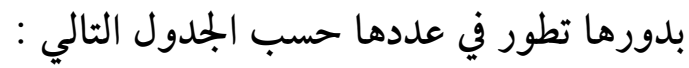

الجدول رقم (02): يوضح تطورعدد المنشاة القاعدية لمراحل التعليم على المستوى الوطني.

\begin{tabular}{|c|c|c|c|}
\hline الثانويات & المتوسطات & الالمدارس & السنة الدراسية \\
\hline 1.218 & 3.315 & 15.729 & $2000 / 1999$ \\
\hline 1.259 & 3.414 & 16.186 & $2001 / 2000$ \\
\hline 1.289 & 3.526 & 16.482 & $2002 / 2001$ \\
\hline 1.330 & 3.650 & 16.714 & $2003 / 2002$ \\
\hline 1.381 & 3.740 & 16.899 & $2004 / 2003$ \\
\hline 1.423 & 3.844 & 17.041 & $2005 / 2004$ \\
\hline 1.473 & 3.947 & 17.163 & $2006 / 2005$ \\
\hline 1.538 & 4.104 & 17.357 & $2007 / 2006$ \\
\hline 1.589 & 4.272 & 17.487 & $2008 / 2007$ \\
\hline 1.699 & 4.584 & 17.796 & $2009 / 2008$ \\
\hline
\end{tabular}


المصدر: دليل الإحصاء السنوي لوزارة التربية الوطنية( بن بوزيد، ص315).

و من خلال تفحصنا لمذه المعطيات نلاحظ و كما تم الإشارة إليه آنفـا ،أن

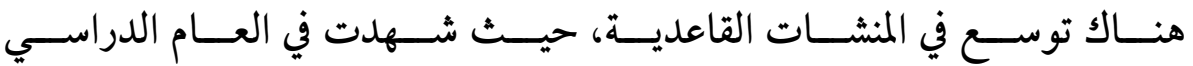

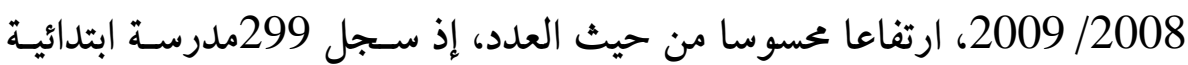

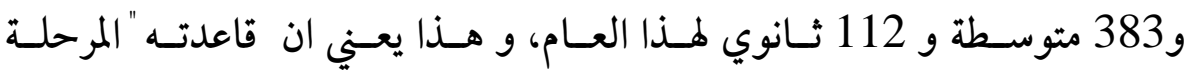

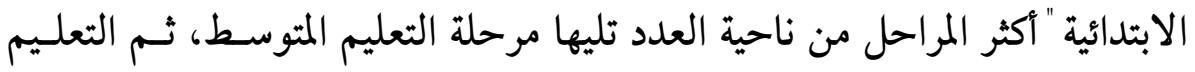

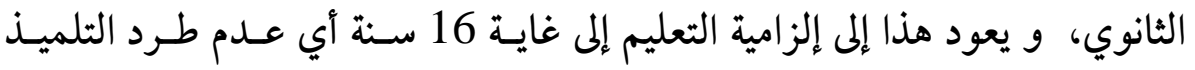

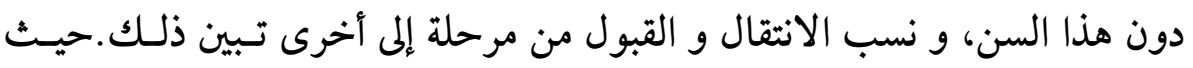

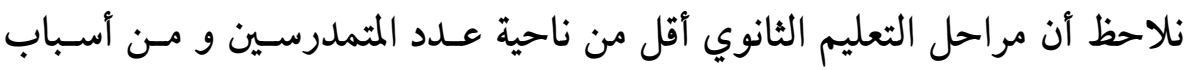

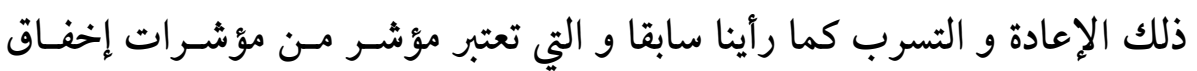
النظام التربوي الاعادة و التسر

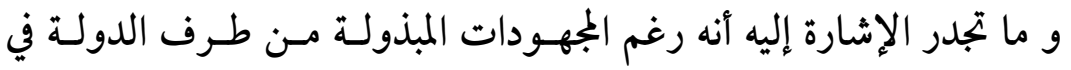

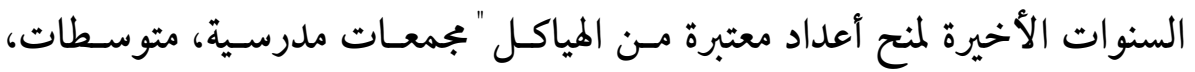

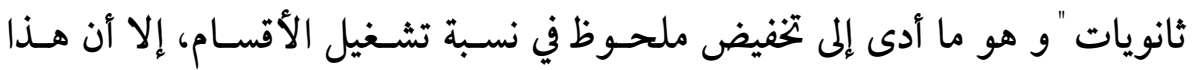
العدد لم يغطي العجز المتراكم في بعض الو الو لايات.

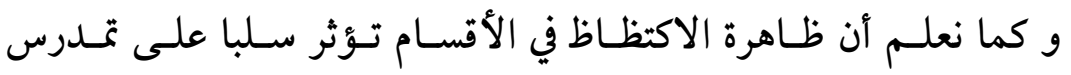

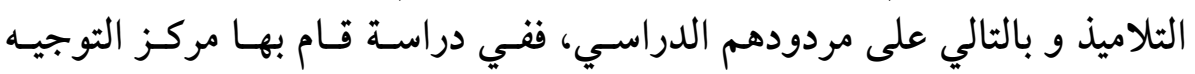

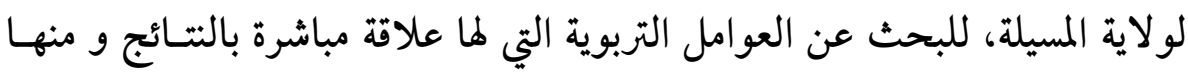

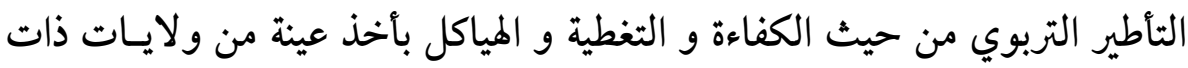

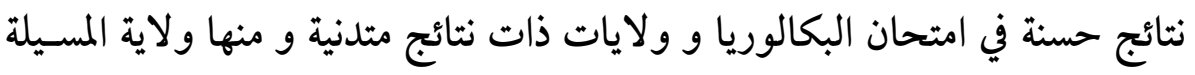

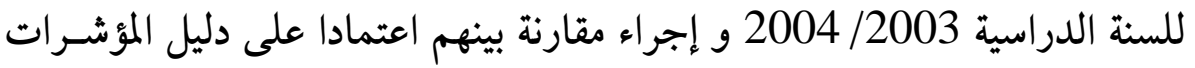

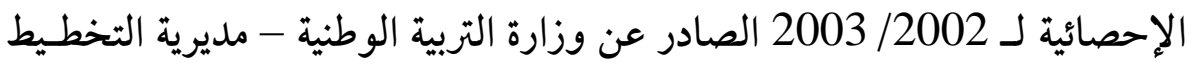

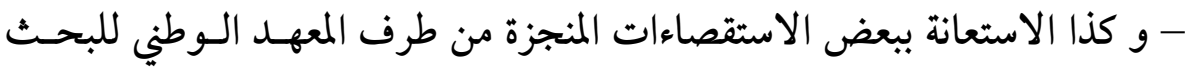




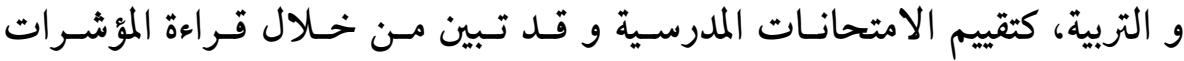
الإحصائية لماتين الجمموعتين كما هي موضحة في: الانيات

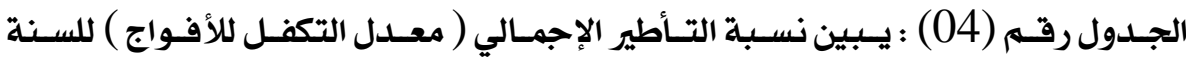
الدراسية 2003/2002 اللتعليم الثانوي:

\begin{tabular}{|c|c|c|c|c|c|}
\hline \multicolumn{3}{|c|}{ الولايات ذات المردود الضعيف } & \multicolumn{3}{|c|}{ الو لايات ذات المردود الحسن } \\
\hline النتيجـــــــــة & رتبــــــــــة & 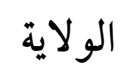 & النتيجـــــــــة & رتبــــــــــــة & 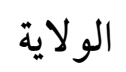 \\
\hline الإحصـــائية & البكالوريـــــا & & الإحصـــائية & البكالوريـــــا & \\
\hline للمؤشر & 2003 & & للمؤشر & 2003 & \\
\hline 38 & $46 / 40$ & i & 32 & $46 / 03$ & i \\
\hline 43 & $46 / 45$ & ب & 35 & $46 / 04$ & ب \\
\hline 37 & $46 / 37$ & ج & 31 & $46 / 15$ & ج \\
\hline 37 & $46 / 41$ & د & 37 & $46 / 23$ & د \\
\hline
\end{tabular}

المصدر: أخذت هذه المعطيات من دراسة قام بها مركز التوجيـه المدرسي والمهني

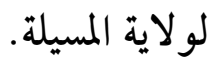

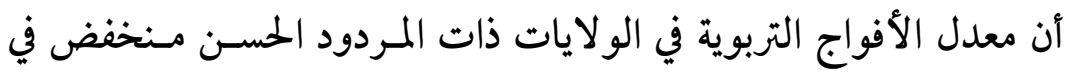

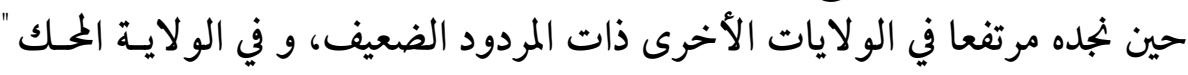

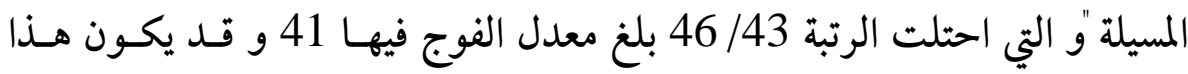
عامل من العوامل التي دفعت إلى الحصول على هذه الرتبة وطنيا في الامتحان. 
الجـدول رقـم (05) يمثـل نسـبة التـأطير الإجمـالي(معـدل التكفـل) في مرحلـة التعلـيم

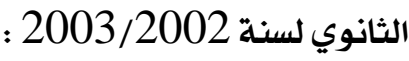

\begin{tabular}{|c|c|c|c|c|c|}
\hline \multicolumn{3}{|c|}{ الولايات ذات المردود الضعيف } & \multicolumn{3}{|c|}{ الولايات ذات المردود الحسن } \\
\hline النتيججــــــــة & رتبـــــــــــة & & النتيجـــــــــة & 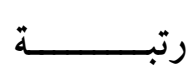 & \\
\hline الإحصـــائية & البكالوريــــا & الولاية & الإحصـــائية & البكالوريــــــا & 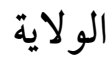 \\
\hline ل للمؤشر & 2003 & & ل ل لمؤشر & 2003 & \\
\hline 21.01 & $46 / 40$ & أ & 16.65 & $46 / 03$ & أ \\
\hline 27.79 & $46 / 45$ & بُ & 17.60 & $46 / 04$ & ب \\
\hline 20.96 & $46 / 37$ & ج & 14.48 & $46 / 15$ & ج \\
\hline 19.60 & $46 / 41$ & د & 19.44 & $46 / 23$ & د \\
\hline
\end{tabular}

المصدر : المعطيات مأخوذة من الدراسة التي قام بها مركز التوجيه المدرسي لولايـة المسيلة مرجع سابق.

و التي بينت أن معدل التكفل "أستاذ / تلميـذ " في الولايـات ذات المـردود

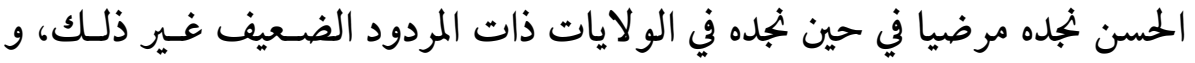

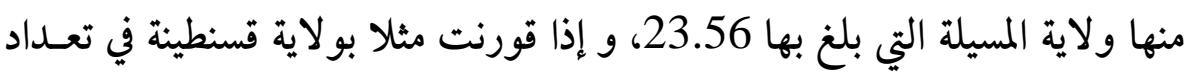

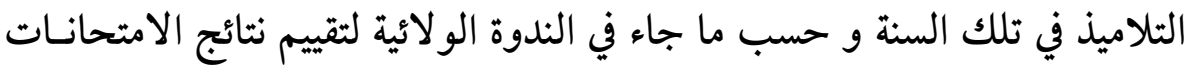

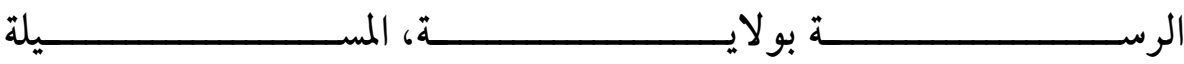


، فإنها تفوقها عددا بـ 1427 تلميذ و بالمقابل تقل عنها بـ 770 منصب مالي أقل

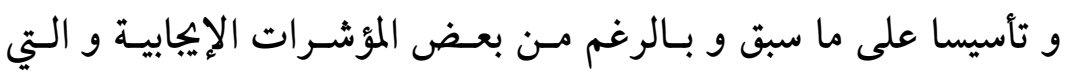

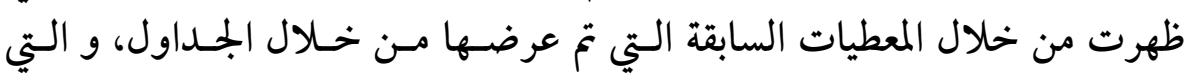

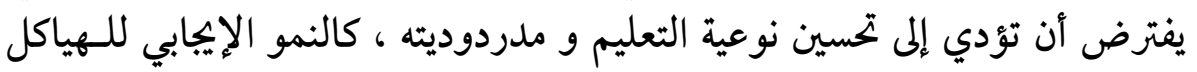

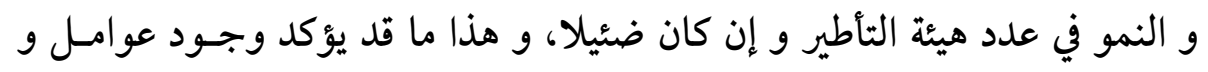

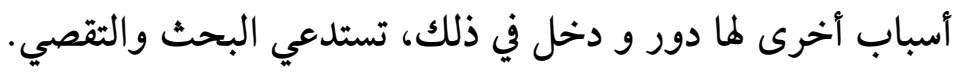

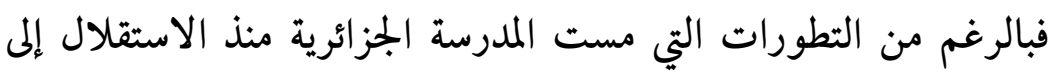

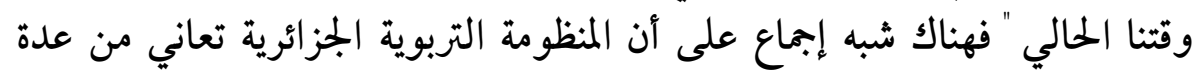

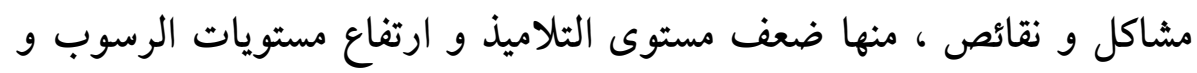

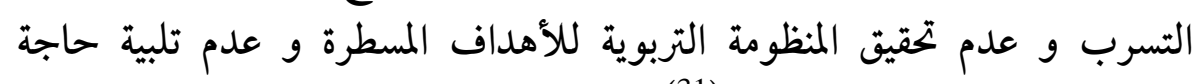
المجتمع من مختلف المهارات المهنية (31).

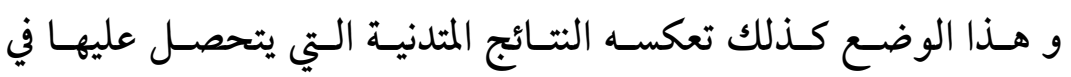

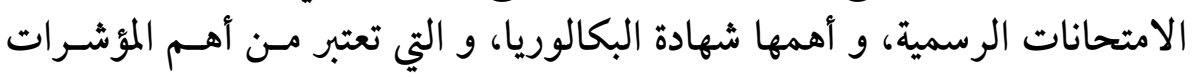

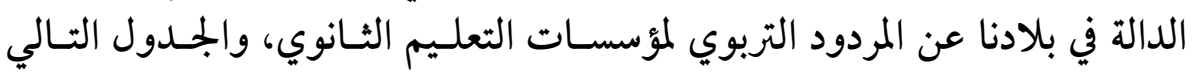
يبين ذلك:

الجدول : رقم (3) يبين نتائج امتحان شهادة البكالوريا من (2001-2008) .

\begin{tabular}{|c|c|c|c|c|c|c|c|}
\hline جو جوان|ن & جوان & جوان & جوان & جوان & & \\
2008 & 2007 & 2006 & 2005 & 2004 & 2003 & 2002 & 2001 \\
\hline 55.04 & 53.29 & 51.15 & 37.29 & 44.52 & 29.55 & 32.92 & 34.46 \\
$\%$ & $\%$ & $\%$ & $\%$ & $\%$ & $\%$ & $\%$ & $\%$ \\
\hline
\end{tabular}




\section{المصدر: (بن بوزيد، مرجع سبق ذكره، ص292)}

وحسب ماهو مبين في الجدول أعلاه وبالرغم من التحسن في نتائج

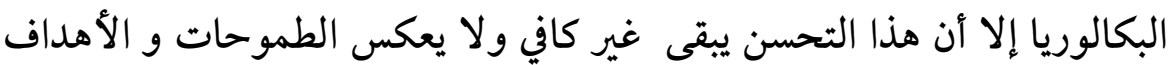

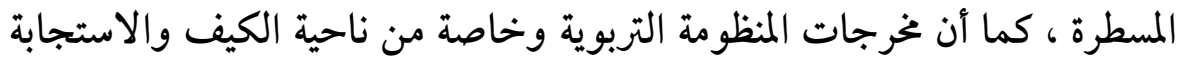

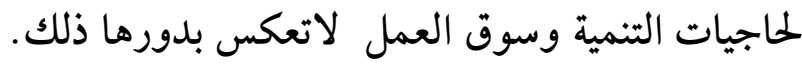

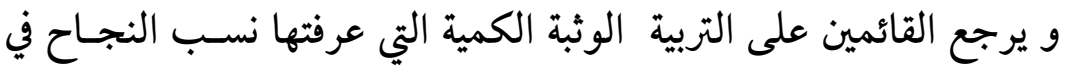

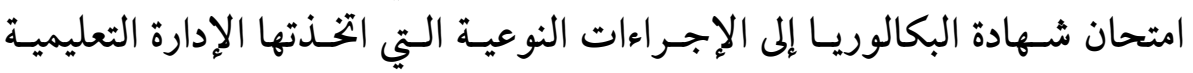

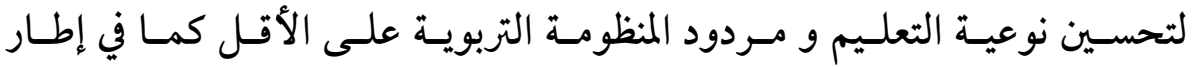

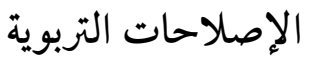

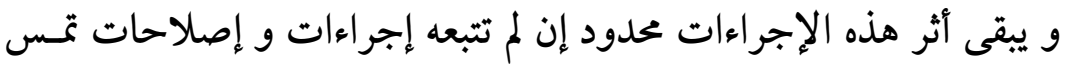

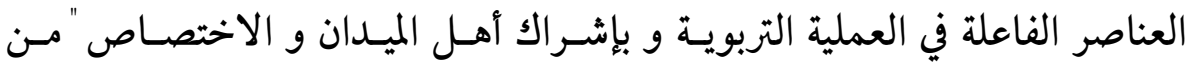

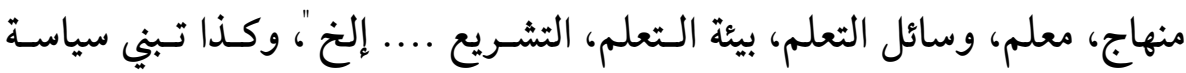

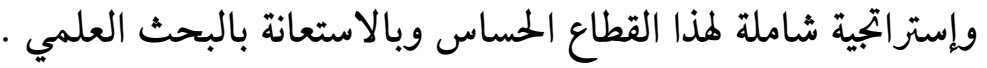


مجلة علوم الإنسان والمجتمع.......................................................... حورية علي شريف

الخاتمة:

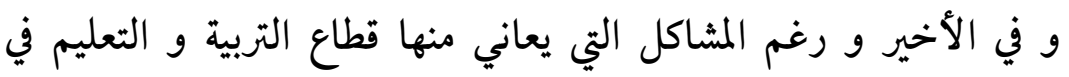

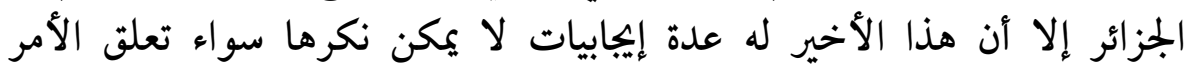

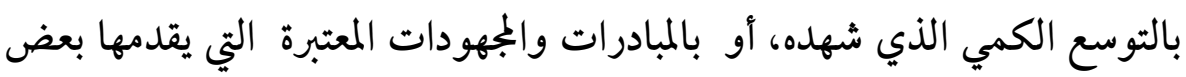

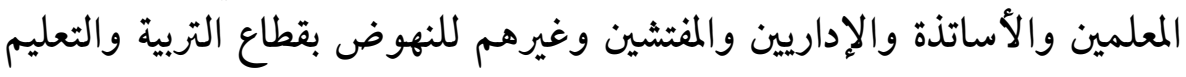

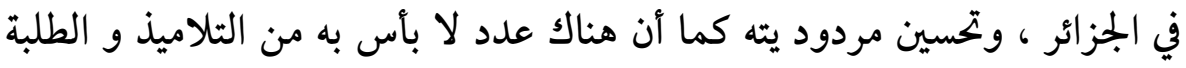

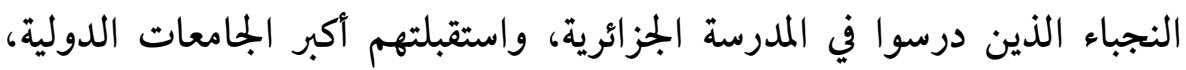

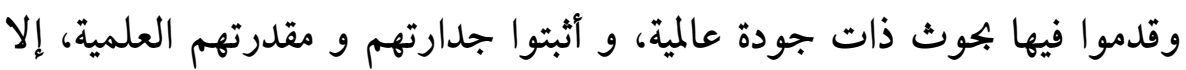

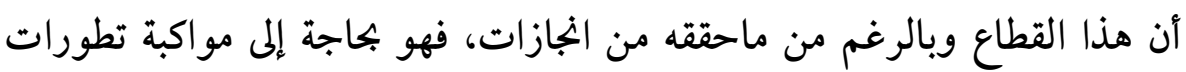
العصر المتسارعة. 


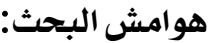

المنجد في اللغة والإعلام، ط2، دار المعرفة، بيروت، 1986، ص255.

(2) Larousse Tome, Grond dictionnaire en cyclopedique, Lebraire larousse P9093.

محمد منير مرسي: تخطيط التعليم واقتصادياته، عالم الكتب، القاهرة، 1998،

ص133.

أحمد إبراهيم أحم: العلاقات الإنسانية في المؤسسات التعليمية، دار الوفاء

$$
\text { محمد منير مرسي: مرجع سبق ذكره، صالإسكندرية، 2002، ص111. }
$$

أحمد إسماعيل حجي: الإدارة التعليمية والإدارة المدرسية،دار الفكر العربي، القاهرة،

$$
\text { علي بن هادية و آخرون : ص2211. رشيد أورلسان : مرجع سبق ذكره، ص147. }
$$

سيد إبر اهيم الجبار: التربية ومشكلات المجتمع - بجموعة دراسات- دار غريب للطباعة

$$
\text { والنشر والتوزيع، القاهرة، ص54. }
$$

(10) وزارة التربية الوطنية: سلسلة تضايا التربية، الملف رقم 18، التصورات النظرية

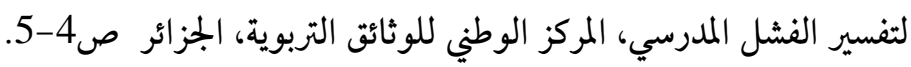

مركز المعلومات الوطني الفلسطيني، ظاهرة التسرب من المدارس الأسباب والاجرات

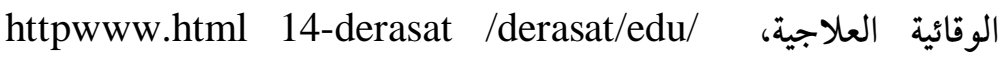
12arabic/ps.gov.pnic ،

$$
\text { على بن هادية و آخرون: مرجع سبق ذكره، ص188. }
$$




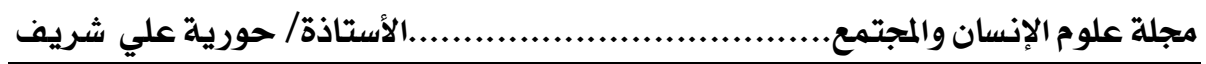

عمر عبد الرحيم نصر الله: أساسيات في التربية العلمية، دار وائل للنشر

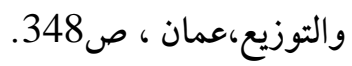

(14) بوبكر بن بوزيد: موعدك التربوي، سلسلة الملفات التربوية ( التسرب المدرسي)،

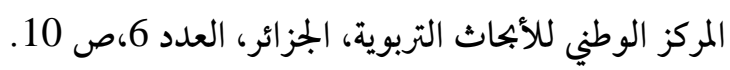

$$
\text { (15) (المرجع نفسه ، ص10. }
$$

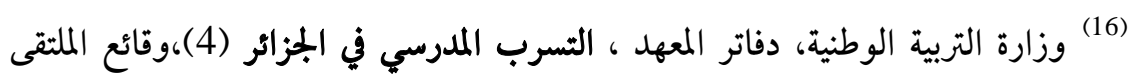

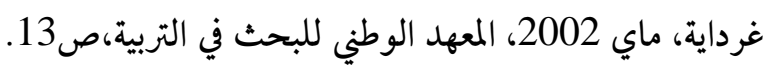
(17) وزارة التربية الوطنية:التسرب المدرسي في التعليم الأساسي الثانوي، مرجع سبق

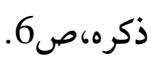

(18) وزارة التربية: موعدك التربوي، التسرب المدرسي،مرجع سبق ذكره،ص ص3-4.

$$
\text { (19) علي بن هادية و آخرون:مرجع سبق ذكره، ص386. }
$$

(20) وزارة التربية الوطنية:دفاتر المعهد، التسرب المدرسي في الجزائر (4) ، مرجع سبق

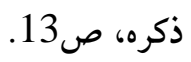

سميرة أحمد: علم اجتماع التربية،دار الفكر العربي، القاهرة،3 ،ص184 وزارة التربية الوطنية: المنشور الوزاري رقم 319 المؤرخ في 09/ 04/ 1997

$$
\text { رالمرجع السابق، ص أرلسان: مرجع سبق ذكره، ص159. }
$$

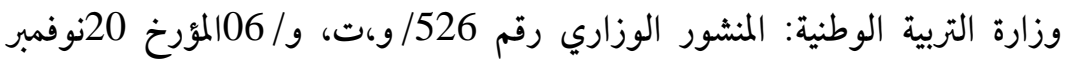

2006و المتعلق بالتكفل بتلاميذ السنة الثالثة ثانوي.

$$
\text { بوفلجة غيات: مرجع سبق ذكره،ص } 69 .
$$

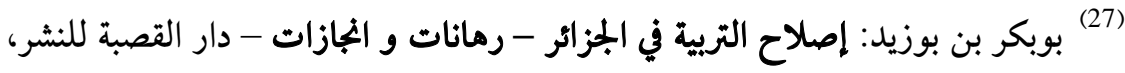

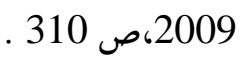




$$
\begin{aligned}
& \text { (28) بوفلجة غياث ،مرجع سابق، ص } 70 . \\
& \text { (29) بوبكر بن بوزيد ، مرجع سابق، ص } 165 \text { (30) }
\end{aligned}
$$

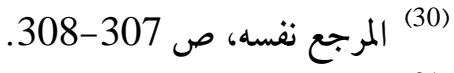

$$
\begin{aligned}
& \text { (31) بوفلجة غيات: مرجع سابق، ص صرسلاته } 153 .
\end{aligned}
$$

